\title{
The Indicating Factors of Oral Reading Fluency of Monolingual and Bilingual Children in Egypt
}

\author{
Abdelaziz M. Hussien ${ }^{1}$ \\ ${ }^{1}$ Department of Curriculum \& Instruction, Faculty of Education, Suez Canal University, Ismailia, Egypt \\ Correspondence: Abdelaziz M. Hussien, Department of Curriculum \& Instruction, Faculty of Education, Suez \\ Canal University, Ismailia, Egypt. E-mail: damhussien@gmail.com
}

Received: December 10, 2013 Accepted: January 11, 2014 Online Published: January 22, 2014

doi:10.5539/ies.v7n2p75

URL: http://dx.doi.org/10.5539/ies.v7n2p75

\begin{abstract}
This study examined oral reading fluency (ORF) of bilingual and monolingual students. The author selected a sample of 510 (258 males and 252 females) native Arabic-speaking sixth-graders (62 bilinguals and 448 monolinguals) in Egypt. The purposes were; (a) to examine oral reading rate, oral reading accuracy, prosody, and oral reading comprehension as indicating factors in ORF, and b) to investigate the impact of bilingual education on students' ORF in Arabic. Participants individually completed the author-developed Oral Reading Fluency Measure. Results indicated a very good fit between the proposed model and the observed data i.e., oral reading rate, oral reading accuracy, prosody, and oral reading comprehension are significant indicators of ORF. Interestingly, results revealed that the bilingual students performed better than their monolingual counterparts on oral reading rate, oral reading accuracy, and prosody but not on oral reading comprehension. The discussion concludes that (a) in addition to oral reading rate, oral reading accuracy, and prosody, oral reading comprehension is a significant indicating factor of ORF, (b) learning a second language, English, has a positive effect on ORF in the first language, Arabic, and (c) the nature of Arabic orthography is an indispensible factor when examining ORF in science of reading.
\end{abstract}

Keywords: oral reading fluency, oral reading comprehension, oral reading rate, oral reading accuracy, prosody, bilingual education, Arabic orthography

\section{Introduction}

It is well-established that fluency plays a critical role in improving overall reading competence (e.g., L. Fuchs, D. Fuchs, Hosp, \& Jenkins, 2001; Rasinski, Rikli, \& Johnston, 2009; Rasinski, Samuels, Hiebert, Petscher, \& Feller, 2011). A review of the literature suggests that oral reading fluency (ORF) refers to reading text quickly, accurately, with good prosody, and with comprehension (e.g., Abdelbari, 2011; Hasbrouck \& Tindal, 2006; Hudson, Lane, \& Pullen, 2005; Hudson, Pullen, Lane, \& Torgesen, 2008; Hussien, 2011; Kuhn, Schwanenflugel, \& Meisineger, 2010; McKenna, 2002; McKenna \& Stahi, 2003; McShane, 2005; Pikulski \& Chard, 2005; Rasinski, 2004; Valencia et al., 2010). Previous research, usually in English, provides considerable knowledge about oral reading accuracy, oral reading rate and prosody as indicating variables in ORF. Much less is known, however, about oral reading comprehension as an indicating factor in ORF (University of Oregon, 2008). In addition, there is a rising interest in the last decade in ORF internationally, with respect to English. Much less attention, however, is dedicated to ORF of Arabic-speaking students (Abdelbari, 2011; Abu-Hajaj, 1999, 2006; Bilal, 2009; Fadal-Allah, 2004; Majawor, 1998). Furthermore, the public education in Egypt, the context of the current study, involves two types of schools mainly monolingual schools and fewer of bilingual schools. The purposes of the study were: (a) to examine oral reading rate, oral reading accuracy, prosody, and oral reading comprehension as indicating factors in ORF, and (b) to investigate the impact of bilingual education on students' ORF in Arabic.

\subsection{The Orthography of Arabic}

In this context, it is important to consider the nature of Arabic orthography since the majority of studies mentioned on ORF has been carried out in English. Arabic is a Semitic language that has unique characteristics. It consists of 28 letters and is read and written from right to left. Its letters are attached to one another and they take different appearances, though the main form is maintained, as a function of their connection to preceding or following letters. Additionally, 15 letters are companied by dots: one, two, or three that are written above or 


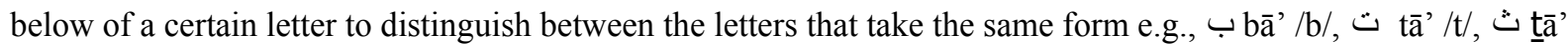
/O/ (Abu-Rabia \& Taha, 2006; Dawood, 2000; Hussien, 2009, 2011). Furthermore, there are three short vowels that facilitate word recognition as they appear above and/or below the letters. In addition, there is a diacritical mark (sukūn) used as an indication of short vowels omission and another one called 'šadda' used as an indication of the lengthening of consonants (doubling the consonant in one letter). Sixth-grade students, as is the case of the current study, are expected to read without visible short vowels depending on context, but younger learners and beginners are introduced to reading through vowelized scripts that help them to read words accurately (Abu-Rabia, 1997, 1999, 2001; Abu-Rabia \& Taha, 2006; Hussien, in press; Mahfoudhi, Everatt, \& Elbeheri, 2011; Taibah \& Haynes, 2011). The point here is that Arabic is a homographic orthography if introduced unvowelized (Abu-Rabia, 1997; Abu-Rabia \& Siegel, 1995, 2003). Words with the same shape can have different pronunciations and meanings as a result of blending of consonants and vowels e.g., /science ع ع / /, /flag

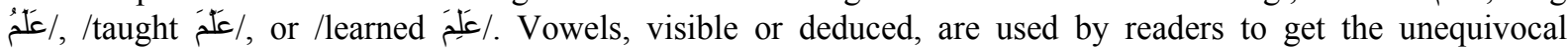
meanings and pronunciations of words. Thus, word recognition in Arabic is a cognitively demanding process that requires processing both letters and vowels and differentiating homographs, if text is unvowelized, which affects oral reading accuracy and comprehension (Abu-Rabia, 1997, 1999, 2001; Hussien, in press).

The other critical issue is that the degree of consistency of orthography, letters and sounds conformities, seems to influence reading skills (Abu-Hajaj, 2006; Furnes \& Samuelsson, 2009; Georgiou, Parrila, \& Papadopoulos, 2008; Goswami, Ziegler, \& Richardson, 2005; Taibah \& Haynes, 2011). Some orthographies are more consistent and have predictable letter-sound relations (e.g., Finnish, Norwegian, German) and hence reading skills can be acquired and improved faster than in less consistent orthographies (e.g., English, Danish, French) (Goswami et al., 2005; Lervag \& Hulme, 2010; Seymour, Aro, \& Erskine, 2003; Taibah \& Haynes, 2011). In contrast to English, Arabic is a consistent orthography either in grapheme-phoneme correspondences or in phoneme-grapheme correspondences (Abu-Hajaj, 2006; Abu-Rabia, 1997, 2001; Mahfoudhi et al., 2011; Taibah \& Haynes, 2011). Nevertheless, Arabic moves from transparency or being shallow to opacity or being deep. It is a shallow orthography when vowelized script is used and it is a deep orthography when text is introduced unvowelized (Abu-Rabia, 2000; Abu-Rabia \& Siegel, 2003; Abu-Rabia \& Taha, 2006; Mahfoudhi et al., 2011; Mohamed, Elbert, \& Landerl, 2011). Additionally, Arabic is an alphabetic orthography with diglossia, mismatch between the colloquial spoken Arabic and literary Arabic, the language of school instruction and most printed media (Abu-Rabia, 2000; Maamouri, 1998; Tahan, Cline, \& Messaoud-Galusi, 2011; Versteegh, 2001). The current study examined ORF through literary Arabic, the language of school instruction. To conclude, the unique characteristics of Arabic orthography should be considered in science of reading (Abu-Rabia, 1997, p. 66, 1998; Hussien, in press), and hence, the nature of Arabic orthography is an important factor in examining ORF in the current study.

\subsection{Indicators of Oral Reading Fluency (ORF)}

As mentioned above, the current study is concerned with examining oral reading rate, oral reading accuracy, prosody, and oral reading comprehension as indicating factors of ORF.

\subsubsection{Oral Reading Rate (ORR)}

Firstly, oral reading rate (ORR), in the current study, refers to the speed at which the child reads words aloud and this speed is measured by calculating the total number of actual words read per minute (Abu-Hajaj, 2006; Daane et al., 2005; Educational Testing Service [ETS], 1995; Harris \& Sipay, 1980; National Institute for Literacy [NIFL], 2003). There is no single reason that explains how many words fluent student can read per minute. Many factors should be considered in this context e.g., the type of genre being read, students' purposes for reading, or the nature of language orthography (Abu-Hajaj, 2006; Fadal-Allah, 2004; Harris \& Sipay, 1980; Hasbrouck \& Tindal, 2006; Hussien, in press).

\subsubsection{Oral Reading Accuracy (ORA)}

Fluent students need accurate word recognition in order to get a proper comprehension of a text. ORA affects comprehension since less-accurate students make some errors and eventually derive insufficient textual information that results in poor or low comprehension (Spooner, Baddeley, \& Gathercole, 2004). Furthermore, ORA in early years seems to predict the development of ORA in later years in the primary school (Oakhill \& Cain, 2012). The current study examined ORA as the ratio of correct words to total possible words students read aloud according to the letter-sound correspondences in Arabic and it is calculated as follows: accuracy level = total words read - errors/total words read (Abdelbari, 2011; NIFL, 2003). The issue is how accurate fluent readers should be? Many researchers (e.g., Abdelbari, 2011; ETS, 1995; Harris \& Sipay, 1980; Hussien, in press; McKenna \& Stahi, 2003) used the reading levels, independent, instructional, and frustration level, to assess 
students' oral reading accuracy. In the current study, fluent students read independently with $98 \%-100 \%$ accuracy. Less fluent students, who are likely to be frustrated, read with less than $90 \%$ accuracy. Students who read a text fluently but need some sort of support read at the instructional level with $90-97 \%$ accuracy. The author discussed these levels of accuracy considering the nature of Arabic orthography, mentioned above.

\subsubsection{Prosody}

In addition, ORR and ORA are necessary but not sufficient to ORF. Since, students may read words at rapid rate and accurately in isolation but may read the same words less fluently in connected texts (NIFL, 2003, p. 23). Prosody, in the current study, refers to reading connected texts smoothly and expressively by which children show that they comprehend what they read orally (Baker \& Valencia, 2012; Miller \& Schwanenflugel, 2008; Rasinski, 2004; McKenna \& Stahi, 2003). Fluent students read with accurate prosody, and this can be judged by observing students while they read orally according to certain rubrics. Some rubrics were developed by the National Assessment of Educational Progress [NAEP] in America in 1992 to classify students into four levels of prosody in English (ETS, 1995; McKenna \& Stahi, 2003). Other rubrics were developed to assess prosody in Arabic (Abdelbari, 2011; Abu-Hajaj, 1993; Ali, 2009; Shehatah, 1981). The current study used three rubrics to assess prosody: (a) phrasing, reading in complete meaningful sentences, (b) smoothness, reading without hesitations or repetitions, and (c) expressiveness, reading with intonation and stopping in each punctuation mark correctly.

\subsubsection{Oral Reading Comprehension (ORC)}

Above all, the ultimate target of reading is comprehension. Researchers document the importance of rate, accuracy, and prosody in order to aid reading comprehension (Benjamin \& Schwanenflugel, 2010; Denton et al., 2011; Hasbrouck \& Tindal, 2006; Kuhn, Strauss, \& Morris, 2006; Mckenna, 2002; McKenna \& Stahi, 2003; Mohamed, 2006; Schwanenflugel et al., 2006; Samuels, 2004; Spooner, Baddeley, \& Gathercole, 2004). Nevertheless, ORC as an indicating factor of ORF, as is the case in the current study, has received very little attention (University of Oregon, 2008). Thus, the current study measured ORC, as an indicating factor of ORF, through three sub-skills: (a) identifying the main idea, (b) identifying details, and (c) making inferences.

\subsection{Context}

This study was conducted in Egyptian primary public schools. These schools involve two types mainly monolingual schools and fewer of bilingual schools. All students in those two types of schools are native Arabic-speaking. The two types of school teach the same subject matters as public schools and the main difference is that in addition to teaching advanced English subject matter, the bilingual schools use English to teach Mathematics and Science. But, the monolingual schools teach very simple English as well. This context raised a critical issue that is the influence of the second language, English, on the first language, Arabic i.e., whether bilingual education affects students' ORF in Arabic or not.

\subsection{The effect of Bilingual Education on ORF in Arabic}

Cook $(1991,1994,2007)$ advocates the notion of multi-competence or the knowledge of more than one language in the same mind. The key principle is that the mind of someone who knows more than one language is different from the mind of a monolingual (Cook, 2003; Kecskes \& Papp, 2000). The argument is that knowledge of more than one language affects and restructures linguistic system and even nonlinguistic cognition in the L2 user's mind (Cook, 2002, 2003; Kecskes, 2010). Learning another language affects the L2 user's first language (Balcom, 2003; Mennen, 2004; Zampini \& Green, 2001). Above all, the first language can be enhanced by learning a second language (Cook, 2003), e.g., Arab university students learning English showed better performance in syntactic processing in Arabic rather than their monolingual counterparts (Noor, 2007), teaching Italian to English children improved their reading in English (Yelland et al., 1993), and learning a second language helped Hungarian secondary school students with the ability to write essays in the first language (Kecskes \& Papp, 2000). The current study examined the effects of English (L2) on students' ORF (L1), and hence it explored the differences between the monolingual school students and the bilingual school students in ORF in Arabic.

\section{Questions of the Study}

Following the foregoing analysis, the current study pursued the following questions;

- What is the level of the sixth grade Arabic-speaking students in ORF?

- To what extent do oral reading rate, oral reading accuracy, prosody, and oral reading comprehension reflect ORF? 
- What is the effect of bilingual education on students' ORF in Arabic?

\section{Methods}

\subsection{Participants}

A convenience sample of 510 (258 males and 252 females) Arabic-speaking sixth-graders (62 bilinguals and 448 monolinguals) was selected from one educational district (Ismailia district). This sample represented 10.2\% percent of the total number of students (community of the study) in the sixth-grade (4984 students) in primary public schools in the district in question. Students were selected from 11 public schools: nine monolingual schools, where Arabic is the medium of instruction and two bilingual schools (Arabic-English). The two types of school teach the same subject matters as public schools and the main difference is that in addition to teaching an advanced English subject matter, the bilingual schools use English to teach Mathematics and Science. But, the monolingual schools teach very simple and basic English as well. Both types of schools teach the same Arabic subject matter as a national and a mother tongue language of all students. In fact, Egyptian education system involves two types of schools mainly monolingual schools and fewer of bilingual schools. Furthermore, socioeconomic status (SES) of students' parents was controlled by using a questionnaire to identify parents' education, income, and occupation. It is well-established in the literature that SES highly correlates with cognitive development and language proficiency (e.g., Bradley \& Corwyn, 2002; Hart \& Risley, 1995; Hoff, Laursen, \& Tardif, 2002; Mercy \& Steelman, 1982). An informed consent form was collected in writing from parents, the Ismailia educational district and the schools where the sample was selected. In addition, an oral consent was obtained from children.

Table 1. Demographic data for the participants from public bilingual and monolingual schools

\begin{tabular}{lll}
\hline Variable & Bilingual students & Monolingual students \\
\hline Age & $\mathrm{M}=146$ months & $\mathrm{M}=145$ months \\
& $\mathrm{SD}=1.8$ & $\mathrm{SD}=2.7$ \\
Gender & Male $=39$ & Male $=220$ \\
& Female $=23$ & Female $=228$ \\
Mother tongue & Arabic & Arabic \\
Medium of instruction & Arabic-English & Arabic \\
Hours of weekly & Average=10.5 Teaching Mathematics, Science, and & Average = 1.5 Teaching \\
English usage & English (advanced) & English (basic) \\
\hline
\end{tabular}

\subsection{Measures}

The researcher developed the Oral Reading Fluency Measure (ORFM). It measures the four indicating factors of ORF: oral reading rate, oral reading accuracy, prosody, and oral reading comprehension. It consists of three unvowelized informational excerpts. The three excerpts or passages (passage $1=230$ words, passage $2=204$ words, passage $3=237$ words) used in ORFM were taken from a reading textbook, which is no longer used in schools, developed by the Ministry of Education (2009) for sixth-grade students in Egypt, and therefore these excerpts are expected to be at grade level and adequately and independently readable by those children. Children had not exposed to these excerpts. The assumption is that testing children while they read more than one passage gives a better account of their ORF rather than reading a single passage (Barth et al., 2012; Burns et al., 2011). ORFM involves two versions: the student's version and teacher's version. In the student's version, there were five multiple choices comprehension questions at the end of each passage to be answered by a student after s/he had finished reading. The teacher's version involves three tables at the end of each passage. The first table was used to write down time a student spent in reading, the second table was used to write down number of errors a student made, and the third table was used to tick the three binary (Yes or No) rubrics of prosody: phrasing, smoothness, and expressiveness.

The researcher made sure that ORFM is a valid and a reliable measure by distributing it to five experts in the field of teaching Arabic and requesting them to judge the measure in terms of the extent this measure operationalizes the four indicating factors of ORF (Cohen, Manion, \& Morrison, 2007) and checking the clarity of the measure. As a consequence, the researcher introduced some amendments in light of experts' comments 
and recommendations e.g., he removed omissions, alterations, additions from prosody factor to avoid overlap and repetition as they were involved in measuring oral accuracy factor. In addition, the researcher applied the ORFM to a pilot sample (22 females and 39 males) and calculated reliability using Cronbach's Alpha $=0.94$ which indicates that ORFM is a reliable measure.

\subsection{Procedures}

ORFM was administered in one single session by school teachers after the researcher had three training sessions with them to explain how the measure can be applied in a consistent way e.g., all teachers had to use a stopwatch to calculate time a student spent in reading and all teachers had to mark any word a student read incorrectly. To make sure teachers were more familiar with ORFM, the researcher requested them to apply the measure to each other once. Each child in the sample was tested individually. A student was requested to read aloud the passage and answer five written multiple choices comprehension questions at the end of the reading, as explained above. The administrator of the instrument (a) calculated time, (b) marked words that are read incorrectly, and (c) ticked the three binary (Yes or No) rubrics of prosody, mentioned above.

\subsection{Analyses}

Descriptive statistics were performed to explain students' level of ORF and an Independent-Samples T Test analysis was conducted to compare between the bilingual and monolingual students' ORF. Confirmatory Factor Analysis (CFA) was performed using the IBM SPSS's Amos 20.0 to test the best model by which oral reading comprehension, oral reading rate, oral reading accuracy, and prosody reflect ORF. Three statistical measures were used to assess goodness of fit (GOF) between the proposed model and the observed data: (a) Chi-square $(\chi 2)$, a non-significant $\chi 2$ indicates adequate model-data fit, (b) normed fit index (NFI), a value of 0.95 suggests appropriate model-data fit, and (c) root mean square error of approximation (RMSEA), a value close to 0.06 indicates adequate model-data fit (Clara, Cox, \& Enns, 2001; Hu \& Bentler, 1999; Schreiber, Stage, King, Nora, \& Barlow, 2006).

\section{Results}

Descriptive statistics revealed that the Median of student's oral reading rate on the three excerpts was 90 w.p.m. It is important, however, to clarify in depth the distribution of students by the number of words read per minute. The Figure 1 depicts the data derived from the ORFM.

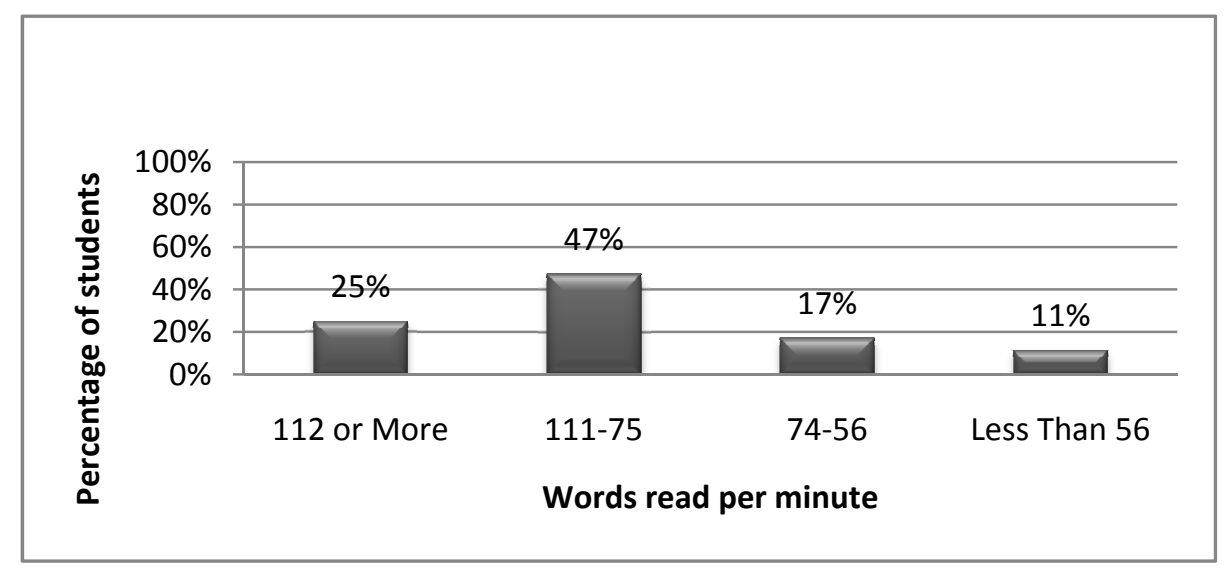

Figure 1. Average number of words read per minute

Figure 1 indicates that $25 \%$ of sixth-grade students read at least 112 w.p.m., well above the median of 90 w.p.m. Moreover, $28 \%$ of students read at or less than 75 w.p.m., substantially less than the median.

In addition to oral reading rate, the results showed the level of student's oral reading accuracy. Figure 2 shows that $41 \%$ of students can read independently, and $46 \%$ of them read at the expected instructional level (read with 97-90 accuracy) and hence need some sort of support to improve oral accuracy. Furthermore, 13\% of students fell at the frustration level and read with less than $90 \%$ accuracy. 


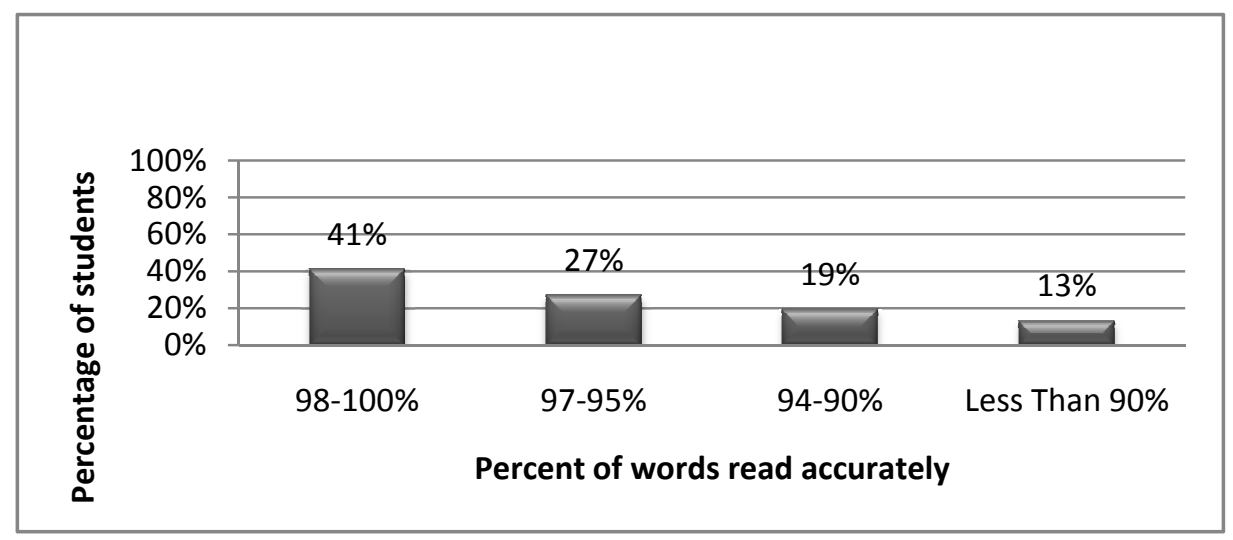

Figure 2. Degree of oral reading accuracy

Examining the level of prosody, Figure 3 shows that $66 \%$ of sixth-grade students read with good prosody, whereas $34 \%$ of them did not.

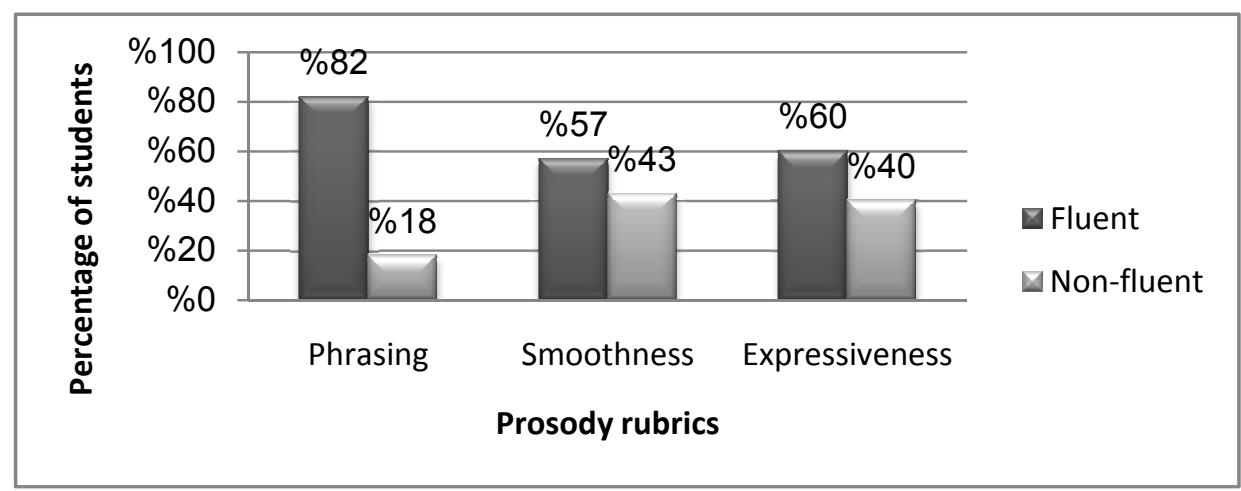

Figure 3. Prosody level

Above all, there were five questions to be answered by a student once s/he had finished reading each passage orally, and these five questions measure three oral reading comprehension components as depicted in the Figure 4.

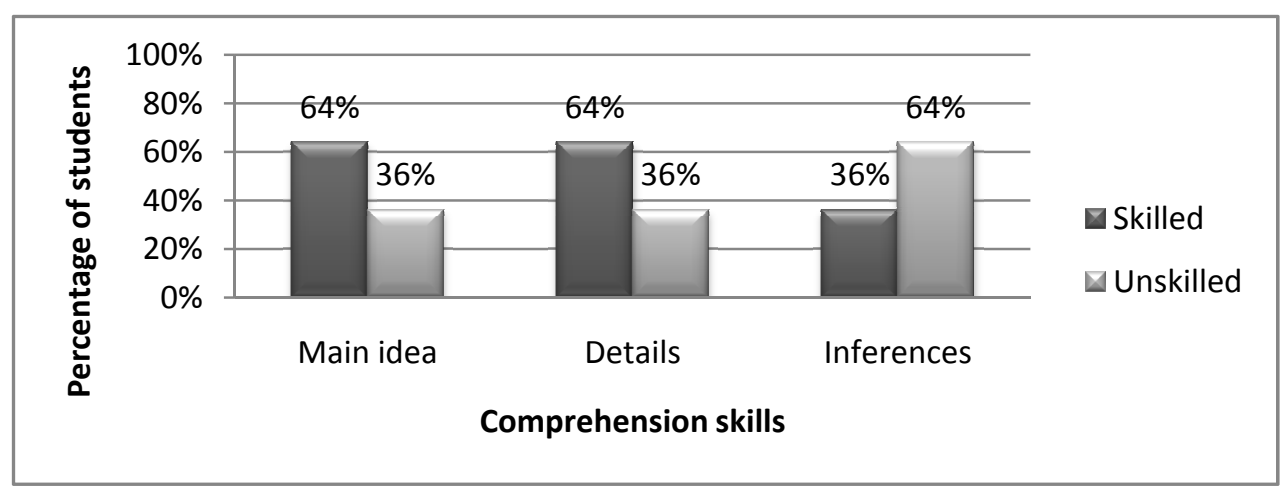

Figure 4. Oral reading comprehension level

Figure 4 indicates that students performed better in identifying the main idea and details than making inferences. Addressing the second core question to the current study, "To what extent do oral reading rate, oral reading accuracy, prosody, and oral reading comprehension reflect ORF?" Confirmatory Factor Analysis was performed. 
Table 2. Model fit summary of oral reading fluency

\begin{tabular}{lllll}
\hline Model & CMIN $\left(\chi^{2}\right)$ & P & NFI & RMSEA \\
\hline Default model & 2.597 & .27 & .996 & .024 \\
Default model & 2.449 & .294 & .996 & .021 \\
Default model & 1.861 & .553 & .998 & .000 \\
Default model & .960 & .619 & .999 & .000
\end{tabular}

Note $1: \mathrm{p}<.05$

Note 2: Four proposed models of indicating factors of ORF were tested

a. The model involves ORR, ORA, prosody, and ORC (i.e. identifying main ideas, identifying details, and making inferences).

b. The model involves ORR, ORA, prosody, and indentifying main idea only.

c. The model involves ORR, ORA, prosody, and identifying details only.

d. The model involves ORR, ORA, prosody, and making inferences only.

Table 2 indicates a very good fit between the four proposed models and the observed data. However, the model is the best model $(\chi 2=.960, \mathrm{p}=.619, \mathrm{NFI}=.999$, RMSEA $=.000)$ indicating ORF in the current study. Despite that all the observed variables in the four models are significant indicators of ORF (all ps $<.000$ ) as depicted in Table 3, prosody, oral reading accuracy, oral reading rate, and making inferences (the observed variables in the model) are the best indicators of ORF in the current study.

Table 3. Estimates of the indicators of oral reading fluency

\begin{tabular}{llccccc}
\hline \multicolumn{1}{c}{ Indicators of ORF } & & Estimate & SE & C.R & P \\
\hline Comprehension & $\longleftarrow$ ORF & .411 & .043 & 9.601 & .000 \\
Identifying main ideas & $\longleftarrow$ ORF & .060 & .012 & 4.969 & .000 \\
Identifying details & $\longleftarrow$ ORF & .158 & .017 & 9.131 & .000 \\
Making inferences & $\longleftarrow$ ORF & .173 & .021 & 8.115 & .000 \\
Prosody & $\longleftarrow$ ORF & 1.0 & & & \\
Oral accuracy & $\longleftarrow$ ORF & .795 & .044 & 17.968 & .000 \\
Oral rate & ORF & .580 & .036 & 16.051 & .000 \\
\hline
\end{tabular}

Note: $\mathrm{p}<.05$.

Answering the third and last key question "What is the effect of bilingual education on students' ORF in Arabic?" An Independent-Samples T Test analysis was conducted as depicted in Table 4. 
Table 4. Results of an Independent-Samples T Test analysis of the bilingual and monolingual students' oral reading fluency

\begin{tabular}{|c|c|c|c|c|c|c|c|c|}
\hline \multirow{3}{*}{ Indicators of ORF } & \multicolumn{6}{|c|}{ Students } & \multirow{3}{*}{$\mathrm{T}$} & \multirow{3}{*}{ Sig. } \\
\hline & \multicolumn{3}{|c|}{ Monolinguals } & \multicolumn{3}{|c|}{ Bilinguals } & & \\
\hline & $\mathrm{N}$ & M & SD & $\mathrm{N}$ & $\mathrm{M}$ & SD & & \\
\hline Oral reading rate & 425 & 87 & 26.8 & 64 & 98 & 26 & 3.070 & .002 \\
\hline Oral reading accuracy & 425 & 9.9 & 2.9 & 65 & 8.8 & 2.4 & 2.640 & .009 \\
\hline Prosody & 401 & 5.9 & 3.1 & 65 & 6.7 & 2.8 & 1.776 & .076 \\
\hline Oral reading comprehension & 426 & 10.9 & 2.8 & 65 & 10.8 & 2.3 & .112 & .911 \\
\hline
\end{tabular}

Note: $\mathrm{p}<.05$.

Table 4 explains that the bilingual students performed better than the monolingual students on oral reading rate, oral reading accuracy, and prosody. However, both bilingual and monolingual students performed at the same level on oral reading comprehension.

\section{Discussion}

The core findings of the current study are that ORC is an indicator of ORF in addition to prosody, ORR, and ORA. The models tested in the current study showed that ORC and each of its examined sub-skills (i.e. identifying main idea, identifying details, and making inferences) are significant indictors of ORF as explained in Table 3. But, the confirmatory factor analysis revealed that the best model of ORF, in the current study, involves prosody, ORR, ORA, and making inferences as depicted in Table 2. That is, researchers and practitioners need to consider the four indicating factors in ORF.

In the literature, many researchers documented the importance of rate, accuracy, and prosody in order to aid reading comprehension (e.g., Benjamin \& Schwanenflugel, 2010; Denton et al., 2011; Hasbrouck \& Tindal, 2006; Kuhn, Strauss, \& Morris, 2006; Mckenna, 2002; McKenna \& Stahi, 2003; Mohamed, 2006). Others related comprehension to reading rate, accuracy, or prosody (e.g., Abbott, Wills, Miller, \& Kaufman, 2012; Ali, 1987; Behari, 1988; El-Essawi, 2002; Daane et al., 2005; Mohamed, 2006). Furthermore, some researchers predicated comprehension by rate, accuracy, or prosody (Binder et al., 2012; Kim, Wagner, \& Foster, 2011; Paleologos \& Brabham, 2011; Riedel, 2007; Wood, 2006).

ORC, in the current study, is rather an indicating factor of ORF. This is consistent with the notion of retell fluency (RTF) to examine comprehension as a factor of ORF in addition to oral rate, oral accuracy, and prosody, which makes ORF one of the best measures of overall reading competence (University of Oregon, 2008). The argument has been made that reading with good prosody, accurately, and rapidly without comprehension means very little (e.g., Chapman \& King, 2003; Hussien, 2009, 2011, in press; Hussien, Beverton, \& Byram, 2009; Pikulski \& Chard, 2005; Wray, 2004). That is, the current study adds to the literature with respect to ORC as an indicating factor of ORF. In addition, the results indicated that examining ORC as an indicating factor of ORF involves both literal (identifying main idea and details) and inferential levels (making inferences).

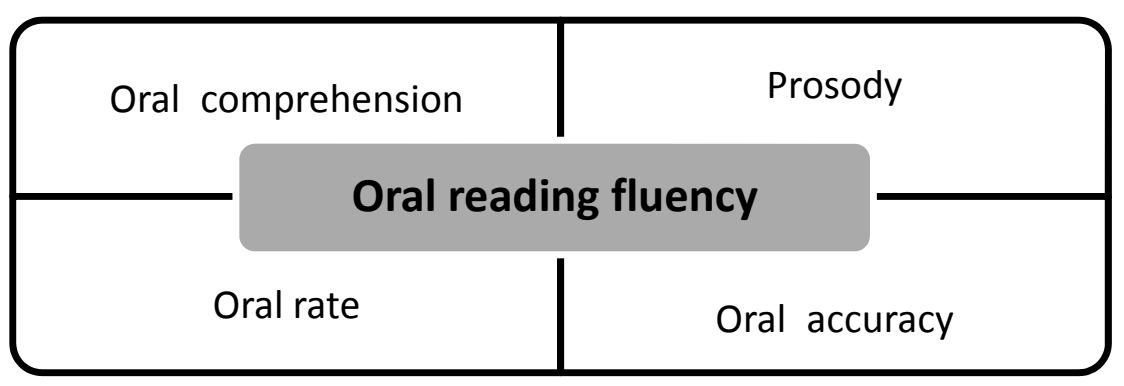

Figure 5. Indicating factors of oral reading fluency 
The second key findings of the current study are that bilingual education significantly affected the students' ORF as explained in Table 4. The bilingual students performed better than their monolingual counterparts on ORR, ORA, and prosody. However, both bilingual and monolingual students performed at the same level on ORC. Interestingly, students in the monolingual school were exposed to Arabic more than English though, the bilingual students were more fluent than monolingual students in ORR, ORA, and prosody. This result is consistent with the notion of multi-competence that learning a second language, English, has positive effects on learning the first language, ORF in Arabic. As explained above, the mind of someone who knows more than one language is different from the mind of a monolingual.

In fact, reading comprehension requires more than reading words accurately at a rapid rate. Context for reading plays a critical role in comprehension (Abu-Rabia \& Siegel, 1995), for example. In this vein, native Arabic-speaking students learning English as a second language transfer local reading strategies, i.e., relevant to single words and sentences, between English (L2) and Arabic (L1) and vice versa (Ghuma, 2011). This also may explain why students learning English (L2), in the current study, performed better than the monolingual students on ORR, ORA, and prosody but not on ORC. Further research is needed to investigate in depth how English (L2) affects Arabic (L1).

The final important findings of the current study are that six-grade Arabic-speaking monolingual and bilingual students performed better in ORR and ORA than in prosody and ORC. For better understanding of these results, a critical issue should be considered that is the unique characteristics of Arabic orthography, as mentioned above.

Referring to the Median of student's ORR (90 w.p.m) stated above. The argument has been made that there is no single reason that explains how many words fluent student can read per minute. ORR depends on many factors chief among them, the nature of orthography (Abu-Hajaj, 2006; Hussien, in press).The orthography of Arabic is a complex i.e., multi-syllabic words (Saiegh-Haddad, 2004), and word recognition in Arabic is a cognitively demanding process that involves processing of letters and vowels, visible or deduced, and differentiating homographs, identical form of words, if text is introduced unvowelized (Abu-Rabia, 1998). This may explain why students who read Arabic, in the current study, had a lower ORR than students who read English, for example. In reading English, 61\% of fourth-graders read a moderately difficult passage at a rate of at least 100 w.p.m. (Pinnell et al., 1995).This emphasizes that the nature of Arabic orthography has indispensible variables e.g., vowels and homographs, to science of reading (Abu-Rabia, 1997, p. 66, 1998; Hussien, in press).

In the same direction, nearly a half of students (46\%) fell at the instructional level (read with $97-90 \%$ accuracy), and $13 \%$ faced difficulty reading passages with less than $90 \%$ accuracy. In this context, a special sort of practice with easier and more readable passages could be useful since practice should be fitted to children's initial reading level (Steenbeek-Planting, Van Bon, \& Schreuder, 2012). Despite the fact that ORA can be improved by practice, the issue here is that ORA in Arabic is also a cognitively demanding process that involves phonological, morphological, and syntactic processes (Abu-Rabia, 1998). To read aloud accurately in Arabic, students need to process letters and vowels. These vowels explain the correct pronunciation, unequivocal meaning, and function of a word in a sentence. The end of a word changes according to its function in a sentence (Abu-Rabia, 1998, p. 107). In fact, these results also suggest that visible vowels, which are not the case in the current study, are important even in the later years in the primary school to read aloud accurately. Students read Arabic vowelized scripts more accurately than unvowelized texts (Abu-Rabia, 1998, 2001; Hussien, in press). Similarly to vowels in Arabic, points in Hebrew (a Semitic orthography like Arabic) help skilled adults with reading aloud accurately (Abu-Rabia, 2001).

Furthermore, reading with good prosody or reading without hesitation or repetition and reading with intonation in Arabic requires students to read words accurately at a rapid rate which in turn involves processing many variables e.g., deducing absent vowels, knowing a function of a word in a sentence, recognizing changes in the end of words and above all, understanding context for reading. This may explain why more than a third of students $(41 \%)$ read with unsmoothly and inexpressively as Figure 3 shows.

Despite the importance of ORR, ORA, and prosody as indicating factors of ORF, teachers need to concentrate on ORC as an indicating factor of ORF and not to stress too much on ORR, ORA or prosody. Hasbrouck and Tindal (2006) suggest that $50 \%$ of fluency in these three factors is enough to start with and to improve comprehension. Previous research also suggests that about 50 word correct per minute (wcpm) among primary school children are needed as a minimum rate or a starting point in comprehension of a text in English (Burns et al., 2002, 2011). Sixth-grade children, in the current study, showed more fluency in literal comprehension, where they were able to identify the main idea and details than in inferential comprehension, where they were requested to make 
inferences from what they read orally, as explained in Figure 4. A plausible explanation of this is that making inferences is more sophisticated than identifying main idea and details which are direct information in a text being read (Al-Naqah \& Hafez, 2002; Mullis, Kennedy, Martin, \& Sainsbury, 2006; Rasslan, 2005; Te'eimah \& El-Shoaibi, 2006; Younis, 2005). In addition, students devote more effort to read words aloud accurately at a rapid rate, and with good prosody, which affects their comprehension (Huey, 1908; LaBerge \& Samuels, 1974; Mckenna, 2002; Nicholson \& Tan, 1999; Samuels, 1976, 2004; Samuels, Schermer, \& Reinking, 1992). In shallow and deep orthographies e.g., Arabic or Hebrew, reading comprehension is affected by the unique characteristics of these Semitic orthographies. Students gained more comprehension of vowelized scripts than unvowelized texts in Arabic (Abu-Rabia, 1999, 2001; Hussien, in press) and similarly, students accomplished more comprehension of pointed texts than unpointed in Hebrew (Abu-Rabia, 1999, 2001; Shimron, 1993; Shimron \& Sivan, 1994). This may also explain why students had difficulty in making inferences from unvowelized scripts used in the current study.

To sum up, these results raise two critical issues that are; (a) Arabic orthography has indispensible variables e.g., vowels, to science of reading, and (b) teachers need to fit their teaching not only to students' initial ORF level but also to the unique characteristics of Arabic orthography. In this context, teachers may use and adjust some techniques to improve ORF in Arabic e.g., fluency-enrichment programs (Reis, Eckert, McCoach, Jacobs, \& Coyne, 2008), fluency-focused interventions (Martens et al., 2007; Schwanenflugel et al., 2009), readers' theatre (Abdelhameed, 2005; Keehn, 2003), repeated reading, choral reading, or peer-reading (Abdelbari, 2011).

\section{Conclusion}

In addition to oral reading rate, oral reading accuracy and prosody, the current study adds to the literature with respect to oral reading comprehension as an indicating factor of ORF. It also provides a comprehensive account about oral reading rate, oral reading accuracy, prosody, and oral reading comprehension in Arabic among sixth-graders, which is a critical step in establishing standards for sixth graders' ORF in Arabic. Interestingly, the current study explains the positive effects of learning a second language, English, on the ORF in the first language, Arabic. Above all, it shows that the nature of Arabic orthography is an indispensible factor when examining ORF in science of reading. Further research is needed to examine ORF in Arabic with different genres e.g., poetry, or narration, and with different conditions i.e., vowelized or unvowelized scripts. In addition, further research is needed to investigate in depth how English (L2) affects Arabic (L1).

\section{References}

Abbott, M., Wills, H., Miller, A., \& Kaufman, J. (2012). The relationship of error rate and comprehension in second and third grade oral reading fluency. Reading Psychology, 33(1-2), 104-132. http://dx.doi.org/10.1080/02702711.2012.630613

Abdelbari, M. S. (2011). فاعلية استراتيجية مقترحة لتنمية مهارات الطلاقة القر ائية لاى تلاميذ المرحلة الابتدائية ] The effectiveness of a proposed strategy for developing reading fluency skills of the primary school students]. Journal of Reading and Literacy, 117, 141-181.

Abdelhameed, A. H. (2005). فعالية استخدام المناهج المسرحية على تتمية مهارات اللغة لدى تلاميذ المرحلة الابتدائية ]The effectiveness of readers' theatre in developing some language skills of the primary school students]. Journal of Reading and Literacy, 50, 15-53.

Abu-hajaj, A. Z. (1993). تنمية مهارات التعبير الثفهي و القراءة الجهرية لدى تلاميذ الصف الخامس من التعليم الأساس (Developing oral language skills of the fifth graders] (Unpublished master thesis. Tanta University, Egypt).

Abu-hajaj, A. Z. (1999). أثر القر اءة المتكررة في تنمية بعض مهارات القراءة لاى تلاميذ المرحلة الابتدائية The effect of repeated reading in developing some reading skills of the primary school students]. Journal of Benha Faculty of Education, 10(32), 239-384.

Abu-hajaj, A. Z. (2006). معدل السرعة في القراءة لاى بعض الطالبات في مر احل التعليم العام والجامعي [Reading rate of female students in the general and university education]. Journal of Reading and Literacy, 61, 130-170.

Abu-Rabia, S. (1997). The need for cross-cultural considerations in reading theory: The effects of Arabic sentence context in skilled and poor readers. Journal of Research in Reading, 20(2), 137-147. http://dx.doi.org/10.1111/1467-9817.00026

Abu-Rabia, S. (1998). Reading Arabic texts: Effects of text type, reader type and vowelization. Reading and Writing: An Interdisciplinary Journal, 10(2), 105-119. http://dx.doi.org/10.1023/A:1007906222227

Abu-Rabia, S. (1999). The effect of Arabic vowels on the reading comprehension of second- and sixth-grade native Arab children. Journal of Psycholinguislic Research, 28(1), 93-101. 
http://dx.doi.org/10.1023/A:1023291620997

Abu-Rabia, S. (2000). Effects of exposure to literary Arabic on reading comprehension in a diglossic situation. Reading and Writing: An Interdisciplinary Journal, 13, 147-157. http://dx.doi.org/10.1023/A:1008133701024

Abu-Rabia, S. (2001). The role of vowels in reading semantic scripts: Data from Arabic and Hebrew. Reading and Writing: An Interdisciplinary Journal, 14, 39-59. http://dx.doi.org/10.1023/A:1008147606320

Abu-Rabia, S., \& Siegel, L. S. (1995). Different orthographies, different context effects: The effects of Arabic sentence context on skilled and poor readers. Reading Psychology, 16(1), 1-19. http://dx.doi.org/10.1080/0270271950160101

Abu-Rabia, S., \& Siegel, L. S. (2003). Reading skills in three orthographies: The case of trilingual Arabic-Hebrew-English-speaking Arab children. Reading and Writing: An Interdisciplinary Journal, 16, 611-634. http://dx.doi.org/10.1023/A:1025838029204

Abu-Rabia, S., \& Taha, H. (2006). Reading in Arabic orthography: Characteristics, research findings and assessment. In R. M. Joshi, \& P. G., Aaron (Eds.), Handbook of Orthography and Literacy (pp. 321-338). Mahwah; NJ: Lawrence Erlbaum Associates.

Ali, F. H. (1987). أثر برنامج مقتر ح لتنمية مهارة السرعة و الفهم في القر اءة الصامتة لدى تلاميذ الصف الساد من التعليم الأساسي effect of a proposed program in developing reading rate and comprehension of sixth grade students] (Unpublished master thesis. Tanta University, Egypt).

Al-Naqah, M., \& Hafez, W. (2002). تعليم اللغة العربية في التعليم العام [Teaching Arabic in the general education]. Cairo: Ain Shams University.

Baker, E. A., \& Valencia, S. (2012, May 25). Examining the validity of oral reading fluency assessments [Audio podcast]. Retrieved from http://voiceofliteracy.org

Balcom, P. (2003). Cross-linguistic influence of L2 English on middle constructions in L1 French. In V. J. Cook (Ed.), Effects of the second language on the first (pp. 168-192). Clevedon: Multilingual Matters Ltd.

Barth, A. E., Stuebing, K. K., Fletcher, J. M., Cirino, P. T., Romain, M., Francis, D., \& Vaughn, S. (2012). Reliability and validity of oral reading fluency median and mean scores among middle grade readers when $\begin{array}{lllll}\text { using } & \text { equated }\end{array}$ http://dx.doi.org/10.1080/02702711.2012.631863

Behari, A. تنمية مهارة السرعة في القراءة الصامتة لاى طلاب المرحلة الثانوية.(Developing silent reading rate in the secondary school] (Unpublished master thesis. Zagazig University, Egypt).

Benjamin, R. G., \& Schwanenflugel, P. J. (2010). Text complexity and oral reading prosody in young readers. Reading Research Quarterly, 45(4), 388-404. http://dx.doi.org/10.1598/RRQ-.45.4.2

Bilal, O. A. (2009). فعالية استر اتيجية مقترحة في تنمية مهارات القراءة الجهرية لاى تلاميذ المرحلة الابندائية [The effectiveness of a proposed strategy in developing oral reading skills of the primary school students] (Unpublished master thesis. Benha University, Egypt).

Binder, K. S., Tighe, E., Jiang, Y., Kaftanski, K., Qi, C., \& Ardoin, S. P. (2012). Reading expressively and understanding thoroughly: An examination of prosody in adults with low literacy skills. Reading and Writing: An Interdisciplinary Journal, 26(5), 665-680. http://dx.doi.org/10.1007/s11145-012-9382-7

Bradley, R. H., \& Corwyn, R. F. (2002). Socioeconomic status and child development. Annual Review of Psychology, 53, 371-399. http://dx.doi.org/10.1146/annurev.psych.53.100901.135233

Burns, M. K., Kwoka, H., Lim, B., Haegele, K., Parker, D. C., Peterson, S., \& Scholin, S. E. (2011). Minimum reading fluency for comprehension among second grade students. Psychology in the Schools, 48(2), 124-132. http://dx.doi.org/10.1002/pits.20531

Burns, M. K., Tucker, J. A., Hauser, A., Thelen, R. L., Holmes, K. J., \& White, K. (2002). Minimum reading fluency rate necessary for comprehension: A potential criterion for curriculum-based assessment. Assessment for Effective Intervention, 28(1), 1-7. http://dx.doi.org/10.1177/073724770202800101

Chapman, C., \& King, R. (2003). Differentiated instructional strategies for reading in the content areas. Thousand Oaks: Corwin Press, Inc.

Clara, I. P., Cox, B. J., \& Enns, M. W. (2001). Confirmatory factor analysis of the depression-anxiety-stress scales in depressed and anxious patients. Journal of Psychopathology and Behavioral Assessment, 23(1), 
61-67. http://dx.doi.org/10.1023/A:1011095624717

Cohen, L., Manion, L., \& Morrison, K. (2007). Research Methods in Education (6th ed.). London: Routledge Falmer.

Cook, V. J. (1991). The poverty-of-the-stimulus argument and multi-competence. Second Language Research, 7(2), 103-117. http://dx.doi.org/10.1177/026765839100700203

Cook, V. J. (1994). The metaphor of access to universal grammar. In N. Ellis (Ed.), Implicit learning and language (pp. 477-502). London: Academic Press.

Cook, V. J. (2007). Multi-competence: Black-hole or worm-hole for second language acquisition research. In Z. Han (Ed.), Understanding second language process (pp. 16-26). Clevedon: Multilingual Matters Ltd.

Cook, V. J. (Ed.). (2002). Portraits of the L2 user. Clevedon: Multilingual Matters Ltd.

Cook, V. J. (Ed.). (2003). Effects of the second language on the first. Clevedon: Multilingual Matters Ltd.

Daane, M. C., Campbell, J. R., Grigg, W. S., Goodman, M. J., Oranje, A., \& Goldstein, A. (2005). Fourth-grade students reading aloud: NAEP 2002 special study of oral reading (NCES 2006-469). Retrieved from http://www.eric.ed.gov/ (ED488962)

Dawood, M. (2000). الصوائت والدعنى في العربية [Vowels and meaning in the Arabic language]. Cairo: Dar Al-Manar for Printing, Publishing \& Distribution.

Denton, C. A., Barth, A. E., Fletcher, J. M., Wexler, J., Vaughn, S., Cirino, P. T., . . Francis, D. J. (2011). The relations among oral and silent reading fluency and comprehension in middle school: Implications for identification and instruction of students with reading difficulties. Scientific Studies of Reading, 15(2), 109-135. http://dx.doi.org/10.1080/10888431003623546

Educational Testing Service. (1995). A synthesis of data from NAEP's 1992 integrated reading performance record (IRPR) at grade 4 [Report]. Princeton, NJ.: Center for the Assessment of Educational progress; National Assessment of Educational Progress.

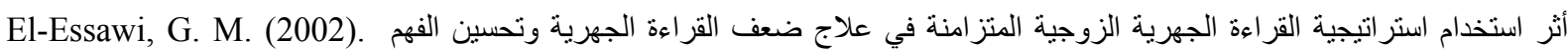
]The effect of peer-oral reading strategy in developing oral reading and comprehension of the third grade struggling readers]. Journal of Reading and Literacy, 23, 15-65.

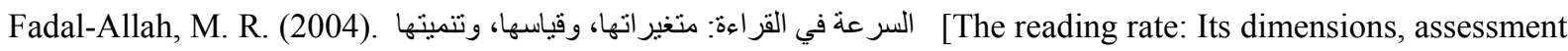
and development]. Journal of Reading and Literacy, 34, 13-49.

Fuchs, L. S., Fuchs, D., Hosp, M. K., \& Jenkins, J. R. (2001). Oral reading fluency as an indicator of reading competence: A theoretical, empirical, and historical analysis. Scientific Studies of Reading, 5(3), 239-256. http://dx.doi.org/10.1207/S1532799XSSR0503_3

Furnes, B., \& Samuelsson, S. (2009). Preschool cognitive and language skills predicting kindergarten and grade1 reading and spelling: A cross-linguistic comparison. Journal of Research in Reading, 32(3), 275-292. http://dx.doi.org/10.1111/j.1467-9817.2009.01-393.x

Georgiou, G. K., Parrila, R., \& Papadopoulos, T. C. (2008). Predictors of word decoding and reading fluency across languages varying in orthographic consistency. Journal of Educational Psychology, 100(3), 566-580. http://dx.doi.org/10.1037/0022-0663.100.3.566

Ghuma, M. (2011). The transferability of reading strategies between L1 (Arabic) and L2 (English) (Unpublished doctoral thesis. Durham University, UK). Retrieved from http://etheses.dur.ac.uk/924/

Goering, C. Z., \& Baker, K. F. (2010). Like the whole class has reading problems: A study of oral fluency activities in a high intervention setting. American Secondary Education, 39(1), 61-78.

Goswami, U., Ziegler, J. C., \& Richardson, U. (2005). The effects of spelling consistency on phonological awareness: A comparison of English and German. Journal of Experimental Child Psychology, 92(4), 345-365. http://dx.doi.org/10.1016/j.jecp.2005.06.002

Harris, A. J., \& Sipay, E. R. (1980). How to increase reading ability (7th ed.). New Jersey: Longman.

Hart, B., \& Risley, T. R. (1995). Meaningful differences in the everyday experience of young American children. Baltimore, MD: Brookes Publishing.

Hasbrouck, J., \& Tindal, G. A. (2006). Oral reading fluency norms: A valuable assessment tool for reading teachers. The Reading Teacher, 59(7), 636-644. 
Hicks, C. P. (2009). A lesson on reading fluency learned from the Tortoise and the Hare. The Reading Teacher, 63(3), 319-323.

Hoff, E., Laursen, B., \& Tardif, T. (2002). Socioeconomic status and parenting. In M. H. Bornstein (Ed.), Handbook of parenting: Vol. 2. Biology and ecology of parenting (2nd ed., pp. 231-252). Mahwah, NJ: Lawrence Erlbaum Associates.

Hu, L., \& Bentler, P. M. (1999). Cutoff criteria for fit indexes in covariance structure analysis: Conventional criteria versus new alternatives. Structural Equation Modeling: A Multidisciplinary Journal, 6(1), 1-55. http://dx.doi.org/10.1080/10705519909540118

Hudson, R. F., Lane, H. B., \& Pullen, P. C. (2005). Reading fluency assessment and instruction: What, why, and how? The Reading Teacher, 58(8), 702-714. http://dx.doi.org/10.1598/RT.58.8.1

Hudson, R. F., Pullen, P. C., Lane, H. B., \& Torgesen, J. K. (2008). The complex nature of reading fluency: A multidimensional view. Reading and Writing Quarterly: Overcoming Learning Difficulties, 25(1), 4-32. http://dx.doi.org/10.1080/10573560802491208

Huey, E. B. (1908). The psychology and pedagogy of reading. New York: Macmillan.

Hussien, A. M. (2009). Designing a reading literacy curriculum for secondary school students in Egypt (Published doctoral thesis. University of Durham, UK). Retrieved from http:/etheses.dur.ac.uk/2116/

Hussien, A. M. (2011). Reading literacy for adolescents. Germany: LAP Lambert Academic Publishing.

Hussien, A. M. (In press). Reading Arabic shallow and deep genres in the fifth and tenth grades: Indispensible variables to science of reading. Journal of Education and Learning.

Hussien, A. M., Beverton, S., \& Byram, M. (2009). Targets for the reading literacy curriculum in the Egyptian secondary school. Journal of Reading, Writing and Literacy, 4(3), 19-38.

Kecskes, I. (2010). Dual and multilanguage systems. International Journal of Multilingualism, 7(2), 91-109. http://dx.doi.org/10.1080/14790710903288313

Kecskes, I., \& Papp, T. (2000). Foreign language and mother tongue. Mahwah; NJ: Lawrence Erlbaum Associates.

Keehn, S. (2003). The effect of instruction and practice through readers theatre on young readers' oral reading fluency. Reading Research and Instruction, 42(4), 40-61. http://dx.doi.org/10.1080/19388070309558395

Kim, Y., Wagner, R. K., \& Foster, E. (2011). Relations among oral reading fluency, silent reading fluency and reading comprehension: A latent variable study of first-grade readers. Scientific Studies of Reading, 15(4), 338-362. http://dx.doi.org/10.1080/10888438.2010.493964

Kuhn, M. R., \& Stahl, S. A. (2003). Fluency: A review of developmental and remedial practices. Journal of Educational Psychology, 95(1), 3-21. http://dx.doi.org/10.1037/00220663.95.1.3

Kuhn, M. R., Schwanenflugel, P. J., \& Meisineger, E. B. (2010). Aligning theory and assessment of reading fluency: Automaticity, prosody, and definitions of fluency. Reading Research Quarterly, 45(2), 230-251. http://dx.doi.org/10.1598/RRQ.45.2.4

LaBerge, D., \& Samuels, J. S. (1974). Toward a theory of automatic information processing in reading. Cognitive Psychology, 6(2), 293-323. http://dx.doi.org/10.1016/0010-0285(74)90015-2

Lervåg, A., \& Hulme, C. (2010). Predicting the growth of early spelling skills: Are there heterogeneous developmental trajectories? Scientific Studies of Reading, 14(6), 485-513. http://dx.doi.org/10.1080/10888431003623488

Maamouri, M. (1998). Language education and human development: Arabic diglossia and its impact on the quality of education in the Arab region. Paper Presented at the Mediterranean Development Forum of the World Bank, Marrakech, Morocco, September, 3-6. Retrieved June 19th, 2009, from http://www.eric.ed.gov

Mahfoudhi, A., Everatt, J., \& Elbeheri, G. (2011). Introduction to the special issue on literacy in Arabic [Special issue]. Reading and Writing: an Interdisciplinary Journal, 24(9), 1011-1018. http://dx.doi.org/10.1007/s11145-011-9306-y

Majawor, M. S. (1998). تدريب اللغة العربية في العرحلة الثانوية [Teaching Arabic in the secondary school]. Cairo: Dar Al-Fikr Al-Arabi for Publishing and Distribution.

Martens, B. K., Eckert, T. L., Begeny, J. C., Lewandowski, L. J., DiGennaro, F. D., Montarello, S. A., . . Fiese, 
B. H. (2007). Effects of a fluency-building program on the reading performance of low-achieving second and third grade students. Journal of Behavioral Education, 16(1), 39-53. http://dx.doi.org/10.1007/s-10864-006-9022-x

McKenna, M. C. (2002). Help for struggling readers: Strategies for grades 3-8. New York: The Duilford Press.

McKenna, M. C., \& Stahi, S. A. (2003). Assessment for reading instruction. New York: The Duilford Press.

McShane, S. (2005). Applying research in reading instruction for adults: First steps for teachers. Retrieved June 26, 2012, from http://lincs.ed.gov/publications/pdf/applyingresearch.pdf

Mellard, D., Woods, K., \& Fall, E. (2011). Assessment and instruction of oral reading fluency among adults with low literacy. Adult Basic Education and Literacy Journal, 5(1), 3-14.

Mennen, I. (2004). Bi-directional interference in the intonation of Dutch speakers of Greek. Journal of Phonetics, 32(4), 543-563. http://dx.doi.org/10.1016/j.wocn.2004.02.002

Mercy, J. A., \& Steelman, L. C. (1982). Familial influence on the intellectual attainment of children. American Sociological Review, 47(4), 532-42.

Miller, J., \& Schwanenflugel, P. J. (2008). A longitudinal study of the development of reading prosody as a dimension of oral reading fluency in early elementary school children. Reading Research Quarterly, 43(4), 336-354. http://dx.doi.org/10.1598/RRQ.43.4.2

Mohamed, H. M. (2006). مستويات القراءة لدى تلاميذ المرحلة الابتدائية وعلاقتها ببعض المتغيرات [Reading levels of the primary school students and their relationships to some variables]. Journal of Reading and Literacy, 57, 197-220.

Mohamed, W., Elbert, T., \& Landerl, K. (2011). The development of reading and spelling abilities in the first 3 years of learning Arabic. Reading and Writing: An Interdisciplinary Journal, 24(9), 1043-1060. http://dx.doi.org/10.1007/s11145-010-9249-8

Mullis, I. V. S., Kennedy, A. M., Martin, M. O., \& Sainsbury, M. (2006). PIRLS 2006 assessment framework and specifications (2nd ed.). Retrieved June 28, 2013, from http://timss.bc.edu/PDF/P06Framework.pdf

National Institute for Literacy. (2003). Put reading first: The research building blocks for reading instruction (2nd ed.). Retrieved June 26, 2012, from http://www.nifl.gov/partnershipforreading/publications/PFRbooklet.pdf

National Institute for Literacy. (2006). Put Reading First: Kindergarten through grade 3: The research building blocks for teaching children to read (3rd ed.). Retrieved June 26, 2012, from http://lincs.ed.gov/publications/pdf/PRFbooklet.pdf

National Institute of Child Health \& Human Development. (2006). Teaching children to read: An evidence-based assessment of the scientific research literature on reading and its implications for reading instruction. $\quad$ Retrieved June 26, 2012, from http://www.dysadd.com/resources/SpecialEd/TeachingChildrenToRead.pdf

Nicholson, T., \& Tan, A. (1999). Proficient word identification for comprehension. In G. B. Thompson, \& T. Nicholson (Eds.), Learning to read (pp. 150-173). Newark, Delaware: International Reading Association.

Noor, H. H. (2007). The influence of L2 on the syntactic processing of L1 by Arab EFL learners. Journal of Literature, Language and Linguistics, 1(1), 1-18.

Oakhill, J. V., \& Cain, K. (2012). The precursors of reading ability in young readers: Evidence from a four-year

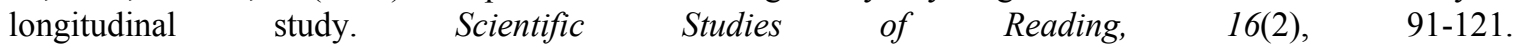
http://dx.doi.org/10.1080/10888438.2010.529219

Paleologos, T. M., \& Brabham, E. G. (2011). The effectiveness of DIBELS oral reading fluency for predicating reading comprehension of high-and low-income students. Reading Psychology, 32(1), 54-74. http://dx.doi.org/10.1080/02702710903341262

Pearce, L. R., \& Gayle, R. (2009). Oral reading fluency as a predictor of reading comprehension with American Indian and White elementary students. School Psychology Review, 38(3), 419-427.

Pikulski, J. J., \& Chard, D. J. (2005). Fluency: Bridge between decoding and reading comprehension. The Reading Teacher, 58(6), 510-520. http://dx.doi.org/10.1598/RT.58.6.2

Pinnell, G. S., Pikulski, J. J., Wixson, K. K., Campbell, J. R., Gough, P. B., \& Beatty, A. S. (1995). Listening to children read aloud: Data from NAEP's integrated reading performance record (IRPR) at grade 4 [Report]. 
Retrieved May 27, 2012, from http://www.eric.e-d.gov/PDFS/ED378550.pdf

Rasinski, T. V. (2004). Assessing reading fluency. Retrieved May 26, 2012, from http://www.prel.org/prod-ucts/re_/assessing-fluency.htm

Rasinski, T. V., Rikli, A., \& Johnston, S. (2009). Reading fluency: More than automaticity? More than a concern for the primary grades? Literacy Research and Instruction, 48(4), 350-361. http://dx.doi.org/10.1080/19388070802468715

Rasinski, T. V., Samuels, S. J., Hiebert, E., Petscher, Y., \& Feller, K. (2011). The relationship between a silent reading fluency instructional protocol on students' reading comprehension and achievement in an urban school setting. Reading Psychology, 32(1), 75-97. http://dx.doi.org/10.1080/02702710903346873

Rasslan, M. (2005). تعليم اللغة العربية [Teaching Arabic language]. Cairo: Dar Althaqafa for Publishing and Distribution.

Reis, S. M., Eckert, R. D., McCoach, D. B., Jacobs, J. K., \& Coyne, M. (2008). Using enrichment reading practices to increase reading fluency, comprehension, and attitudes. The Journal of Educational Research, 101(5), 299-315. http://dx.doi.org/10.3200/JOE-R.101.5.299-315

Riedel, B. W. (2007). The relation between DIBELS, reading comprehension, and vocabulary in urban first-grade students. Reading Research Quarterly, 42(4), 546-567. http://dx.doi.org/10.1598/RRQ.42.4.5

Saiegh-Haddad, E. (2004). The impact of phonemic and lexical distance on the phonological analysis of words and pseudowords in a diglossic context. Applied Psycholinguistic, 25(4), 495-512. http://dx.doi.org/10.1017/S0142716404001249

Samuels, J. S. (1976). Automatic decoding and reading comprehension. Language Arts, 53(3), 323-325.

Samuels, J. S. (2004).Toward a theory of automatic information processing in reading, revisited. In R. B. Ruddell, \& N. J. Unrau (Eds.), Theoretical Models and Processes of Reading (5th ed., pp. 1127-1148). Newark, Delaware: International Reading Association.

Samuels, J. S., Schermer, N., \& Reinking, D. (1992). Reading fluency: Techniques for making decoding automatic. In S. J. Samuels, \& A. E. Farstrup (Eds.), What research has to say about reading instruction (2nd ed., pp. 124-144). Newark, Delaware: International Reading Association.

Schreiber, J. B., Stage, F. K., King, J., Nora, A., \& Barlow, E. A. (2006). Reporting structural education modeling and confirmatory factor analysis results: A review. The Journal of Educational Research, 99(6), 323-338. http://dx.doi.org/10.3200/JOER.99.6.323-338

Schwanenflugel, P. J., Kuhn, M. R., Morris, R. D., Morrow, L. M., Meisinger, E. B., Woo, D. G., .. Sevcik, R. (2009). Insights into fluency instruction: Short- and long-term effects of two reading programs. Literacy Research and Instruction, 48(4), 318-336. http://dx.doi.org/10.1080/19388070802422415

Schwanenflugel, P. J., Meisinger, E. B., Wisenbaker, J. M., Kuhn, M. R., Strauss, G. P., \& Morris, R. D. (2006). Becoming a fluent and automatic reader in the early elementary school years. Reading Research Quarterly, 41(4), 496-522. http://dx.doi.org/10.1598/RRQ.41.4.4

Seymour, P. H. K., Aro, M., \& Erskine, J. M. (2003). Foundation literacy acquisition in European orthographies. British Journal of Psychology, 94(2), 143-174. http://dx.doi.org/10.1348/000712603321661859

Shehatah, H. S. (1981). تطور مهارات القراءة الجهرية في مراحل التعليم العام في مصر/2The development of oral reading skills in the general education in Egypt] (Unpublished doctoral Thesis. Ain Shams University, Egypt).

Shimron, J. (1993). The role of vowels in reading: A review of studies of English and Hebrew. Psychological Bulletin, 114(1), 52-67. http://dx.doi.org/10.1037/0033-2909.114.1.52

Shimron, J., \& Sivan, T. (1994). Reading proficiency and orthography: Evidence from Hebrew and English. Language Learning, 44(1), 5-27. http://dx.doi.org/10.1111/j.1467-1770.1994.tb01447.x

Silber, J. M., \& Martens, B. K. (2010). Programming for the generalization of oral reading fluency: Repeated readings of entire text versus multiple exemplars [Special issue]. Journal of Behavioral Education, 19(1), 30-46. http://dx.doi.org/10.1007/s10864-010-9099-0

Spooner, A. L., Baddeley, A. D., \& Gathercole, S. E. (2004). Can reading accuracy and comprehension be separated in the Neale analysis of reading ability? British Journal of Educational Psychology, 74(2), 187-204. http://dx.doi.org/10.1348/000709904773839833

Steenbeek-Planting, E. G., Van Bon, W. H. J., \& Schreuder, R. (2012). Improving word reading speed: 
Individual differences interact with a training focus on successes of failures. Reading and Writing: An Interdisciplinary Journal, 25(9), 2061-2089. http://dx.doi.org/10.1007/s11145-011-9342-7

Tahan, S. Cline, T., \& Messaoud-Galusi, S. (2011). The relationship between language dominance and pre-reading skills in young bilingual children in Egypt [Special issue]. Reading and Writing: An Interdisciplinary Journal, 24(9), 1061-1087. http://dx.doi.org/10.1007/s11145-011-9301-3

Taibah, N. J., \& Haynes, C. W. (2011). Contributions of phonological processing skills to reading skills in Arabic speaking children [Special issue]. Reading and Writing: An Interdisciplinary Journal, 24(9), 1019-1042. http://dx.doi.org/10.1007/s11145-010-9273-8

Te'eimah, R., \& El-Shoaibi, M. (2006). تعليم القراءة والأبب: استر/تيجيات مختلفة لجمهور متنوع [Teaching reading and Literature: Different strategies for various audiences]. Cairo: Dar Al-Fikr Al-Arabi for Publishing and Distribution.

University of Oregon, Center on Teaching and Learning. (2008). DIBELS oral reading fluency and retell fluency. Retrieved May 28th, 2012, from http://dibels.uoregon.edu/measures/orf.ph-p

Valencia, S. W., Smith, A. T., Reece, A. M., Li, M., Wixson, K. K., \& Newman, H. (2010). Oral reading fluency assessment: Issues of construct, criterion, and consequential validity. Reading Research Quarterly, 45(3), 270-291. http://dx.doi.org/10.1598/RRQ.45.3.1

Versteegh, K. (2001). The Arabic language. Edinburgh: Edinburgh University Press.

Wood, D. E. (2006). Modeling the relationship between oral reading fluency and performance on a statewide reading test. Educational Assessment, 11(2), 85-104. http://dx.doi.org/10.1207/s1-5326977ea1102_1

Wray, D. (2004). Teaching literacy using texts to enhance learning. London: David Fulton Publishers.

Yelland, G. W., Pollard, J., \& Mercuri, A. (1993). The metalinguistic benefits of limited contact with a second language. Applied Psycholinguistics, 14(4), 423-444. http://dx.doi.org/10.1017/S0142716400010687

Younis, F. A. (2005). استر/تيجيات تعليم اللغة العربية في المرحلة الثانوية/23trategies for teaching Arabic for secondary school students]. Cairo: Ain Shams University.

Zampini, M. L., \& Green, K. P. (2001). The voicing contrast in English and Spanish: The relationship between perception and production. In J. L. Nicol (Ed.), One mind, two languages: Bilingual language processing (pp. 23-48). Oxford: Blackwell Publishers Ltd.

\section{Copyrights}

Copyright for this article is retained by the author(s), with first publication rights granted to the journal.

This is an open-access article distributed under the terms and conditions of the Creative Commons Attribution license (http://creativecommons.org/licenses/by/3.0/). 